\title{
First study of fossil rodent middens as source of paleoparasitological evidences (northwestern Patagonia, Argentina)
}

María Ornela Beltrame ${ }^{1,2}$; María Eugenia De Porras ${ }^{3}$; Ramiro Barberena ${ }^{2,4}$, Carina Lourdes Llano ${ }^{2,4}$; Norma Haydée Sardella ${ }^{1,2}$

${ }^{1}$ Laboratorio de Paleoparasitología y Arqueología Contextual, Departamento de Biología, Facultad de Ciencias Exactas y Naturales, Universidad Nacional de Mar del Plata, Funes 3250, 7600 Mar del Plata, Buenos Aires, Argentina ${ }^{2}$ Consejo Nacional de Investigaciones Científicas y Técnicas (CONICET), Buenos Aires, Argentina

${ }^{3}$ Centro de Estudios Avanzados en Zonas Áridas (CEAZA), Universidad de La Serena, La Serena, Chile ${ }^{4}$ Laboratorio de Paleoecología Humana, Facultad de Ciencias Exactas y Naturales, Universidad Nacional de Cuyo, Mendoza, Argentina

Corresponding Author: Beltrame María Ornela

e-mail address: ornelabeltrame@hotmail.com

Phone number: 00549223155945985

Postal address: Laboratorio de Paleoparasitología y Arqueología Contextual, Departamento de Biología, Facultad de Ciencias Exactas y Naturales, Universidad Nacional de Mar del Plata, Funes 3250, (7600) Mar del Plata, Buenos Aires, Argentina. 


\section{ABSTRACT}

The present paper reports the first paleoparasitological results obtained from coprolites of fossil rodent middens and demonstrates the potential of rodent middens as a source of paleoparasitological evidences in South America. Ten fossil rodent middens from northwestern Patagonia, Argentina, were studied. Five coprolites of each midden were fully processed, rehydrated, homogenized, subjected to spontaneous sedimentation, and examined through light microscopy. Eight of the 10 examined rodent middens contained parasite eggs. The eggs of parasites were assigned to Heteroxynema (Cavioxyura) viscaciae Sutton \& Hugot, 1989 and Helminthoxys sp. (Nematoda: Oxyuridae), Trichuris sp. (Nematoda: Trichuridae) and one unidentified nematode. Fossil rodent middens were assigned to Lagidium viscacia (Caviomorph:

Chinchillidae). The excellent preservation of parasite remains in coprolites from fossil rodent middens provided an opportunity to performe paleoparasitological inferences. The results of this papers demonstrates that fossil rodent middens offer an excellent opportunity for the recovery of parasite remains for future paleoparasitological studies in the southwest of South America.

KEYWORDS: fossil rodent middens - coprolites - paleoparasitology -

Patagonia

\section{INTRODUCTION}


Rodent middens are accumulations of organic debris (plant macrofossils, coprolites, pollen) and sediment, encased in hardened urine preserved in rockshelters, caves and crevices [1]. When water from rodent urine is evaporated, these accumulations hardened, allowing the preservation of the deposited materials which can remain intact for several thousand years [2].

Studies of South American fossil rodent middens have been mainly focused on the analysis of pollen and plant macrofossil records. Such studies provided fundamental paleoecological and paleoclimatological evidence from arid and semi-arid regions of South America for the late Quaternary (last 50ka) [2- 8]. Midden agents in South America includes rodent genera such as Lagidium spp. (Chinchillidae), Phyllotis spp. (Cricetidae), Abrocoma spp. (Abrocomidae), Microcavia spp. (Caviidae), Octomys sp. and Octodontomys sp. (Octodontidae) [2]. Rodent middens have become a valuable archive in arid and semi-arid regions of South America due to their multiproxy evidence which allows to address questions in diverse areas of knowledge such as botany, zoology, ecology, biogeography, archaeology, climatology, molecular biology, among others.

Paleoparasitoloical studies have been traditionally applied to coprolites, mummified remains and latrines which are the most common sources of evidences [9]. During the past few years, several samples of rodent coprolites collected from archaeological and paleontological sites from Patagonia were examined for parasites [10-16] providing important insights into the biodiversity of parasites in ancient times. In that sense, the presence of rodent parasites in fossil middens would provide useful and valuable information, as rodent paleoparasitological data can be used from several point of views [17]. Despite 
their unique conditions for preservation in arid and semi-arid settings from

South America, fossil rodent middens have not been used for paleoparasitological purposes.

The present paper reports, therefore, the first paleoparasitological results obtained from coprolites of fossil rodent middens from northwestern Patagonia, Argentina and demonstrates the potential of rodent middens as a source of paleoparasitological evidences in South America.

\section{MATERIAL AND METHODS}

Northwestern Patagonia is located on the lee side of the Andes and the adjacent volcanic fields and plateaus between $35^{\circ}-39^{\circ} \mathrm{S}$. The region is characterized by a west-east climatic gradient from humid conditions along the Andes and dry conditions at the easternmost tip. Vegetation distribution follows the west-east climatic and environmental gradient ranging from the forest and the grass steppes at the lee side of the Andes to the shrub steppes developing on volcanic fields and plateaus $[18,19]$.

The Huenul locality, where rodent middens were collected, is located near the grass steppe- shrub steppe (locally known as Monte) ecotone, at the easternmost tip of the climatic gradient. It is close to Cueva Huenul 1 archaeological site ( $\mathrm{CH} 1)\left(36^{\circ} 56^{\prime} 45^{\prime \prime} \mathrm{S}, 69^{\circ} 47^{\prime} 32^{\prime \prime} \mathrm{W}\right)$ which presents excellent preservation conditions of archaeological and paleontological deposits [20, 21].

Ten fossil rodent middens were collected at Huenul site and specifically together to $\mathrm{CH} 1$ and within a $200 \mathrm{~m}$-far gorge from $\mathrm{CH} 1$ (Fig. 1; Table 1). Eight 
of the ten middens were ${ }^{14} \mathrm{C}$ dated at LATYR (Laboratorio de Tritio $\mathrm{y}$ Radiocarbono, Argentina) and calibrated with the Southern Hemisphere curve (SHCal13; Hogg et al., 2013) from CALIB 7.0.2 program (Table 1). Five coprolites from each rodent midden were examined for parasites. Coprolites were inventoried and processed individually. The examination of the external shape of feces was conducted according to Chame [22] and Jouy-Avantin [23]. Each coprolite was fully processed by rehydration in a $0.5 \%$ water solution of tris-sodium phosphate (TSP) in a glass tube for a week, followed by homogenization, processed by spontaneous sedimentation [24] and preserved in $70 \%$ ethanol. Ten slides were prepared from each coprolite, along with the addition of one drop of glycerin to each slide, and were examined using light microscopy. Eggs of parasites were measured and photographed at $400 \mathrm{X}$ magnification. Broken eggs were discarded.

\section{RESULTS}

Coprolites were dark brown and cylindrical, with smooth surfaces (Fig. 2). Average measurements of feces $(\mathrm{N}=50)$ were $10.3 \pm 1.1 \mathrm{~mm}$ long by $3.7 \pm 0.7$ $\mathrm{mm}$ wide.

Eight of the ten rodent middens examined contained parasite eggs (Table 1). Sixteen coprolites contained eggs of nematodes. Eggs of parasite were assigned to Heteroxynema (Cavioxyura) viscaciae Sutton \& Hugot, 1989 and Helminthoxys sp. (Nematoda: Oxyuridae), Trichuris sp. (Nematoda: Trichuridae) and one unidentified nematode. 
Eggs of $H$. viscaciae (Fig. 3), with single thick wall and with a rounded pole and the other sharp, without operculum, were found in 5 coprolites from 4 middens. Average egg measurements $(\mathrm{N}=5)$ were 137.5 to $152.5(143.5 \pm 5.47)$ $\mu \mathrm{m}$ long by 62.5 to $67.5(65.63 \pm 2.39) \mu \mathrm{m}$ wide.

Asymmetrical and yellowish eggs, with only one side convex and thin and smooth wall, with a dark-yellow embryonic mass, were assigned to Helminthoxys sp. (Fig. 4) and were found in 6 coprolites from five middens. Average egg measurements $(\mathrm{N}=20)$ were as follows: 100.0 to $112.5(106.9 \pm$ 4.12) $\mu \mathrm{m}$ long by 42.5 to $55.0(48.63 \pm 3.19) \mu \mathrm{m}$ wide.

Eggs of Trichuris sp. (Fig. 5) were observed in 4 coprolites from 4 different rodent middens. These eggs were lemon shaped, with a smooth surface and polar plugs. Measurements of eggs were different between middens, and were attributed to two different Trichuris species. Average egg measurements $(\mathrm{N}=6)$ from one of the middens were as follows: 70.0 to 77.5 (74.17 \pm 2.58$) \mu \mathrm{m}$ without plugs and 77.5 to $80.0(79.00 \pm 1.37) \mu \mathrm{m}$ with plugs long by 37.5 to $40.0(38.5 \pm 1.37) \mu \mathrm{m}$ wide. From 2 middens only one egg in each one were found. Measurements were $55 \mu \mathrm{m}$ without plugs and $65 \mu \mathrm{m}$ with plugs long by $42,5 \mu \mathrm{m}$ wide and $60 \mu \mathrm{m}$ without plugs long by $32,5 \mu \mathrm{m}$ wide. Two Trichuris eggs were found in another midden, their measurements were 52,5 and $57,5 \mu \mathrm{m}$ without plugs and 60 and $62,5 \mu \mathrm{m}$ with plugs by $30 \mu \mathrm{m}$ wide.

Two oval and embryonated egg belong to an unidentified nematode were found in one coprolite, the measurements were $45 \mu \mathrm{m}$ by $40 \mu \mathrm{m}$ (Figure 6).

\section{DISCUSSION}


Species of oxyurid nematodes are monoxenic parasites that live in the posterior third of the digestive tract of various vertebrates and arthropods [25]. Oxyuroidea from vertebrates can be grouped into 3 families: Pharyngodonidae, Oxyuridae and Heteroxynematidae [26]. Heteroxynematidae includes nematodes that evolved in sciuromorph, caviomorph and miomorph mammals. Heteroxynema viscaciae (Heteroxynematidae) is a parasite found in the caecum and large intestine from Lagidium viscacia from Chubut Province, Argentina, first described by Hugot and Sutton [27]. It was also observed by Foster et al. [28] and by Ferreira et al. [29] from the wild viscachas Lagostomus maximus from La Pampa and Chaco Provinces (Argentina), respectively. Heteroxynema viscaciae was also found in ancient coprolites assigned to $L$. viscacia from Cueva Huenul 1 [14] and from the paleontological site Los Altares [16].

Several studies have demonstrated the high host-specificity among Oxyuridae (e.g. 30, 31]. In particular, these studies showed that the distribution of Syphaciinae belonging to the same family of rodent hosts have a closely parallel phylogeny with them. Helminthoxys sp. (Oxyuridae: Syphaciinae) is a parasite of neotropical caviomorph rodents. The genus Helminthoxys comprises seven species: H. caudatus (syn. H. pujoli), H. effilatus (syn. H. velizi), $H$. freitasi, H. tiflophila, H. quentini, H. urichi, H. gigantea and H. abrocomae [32]. The measurements and morphology of eggs found in this study are similar to those of $H$. caudatus, described parasitizing Microcavia australis from Los Altares, Chubut Province, Argentina [33].

Trichuris spp. include intestinal parasites of the caecum and colon of mammals, mainly humans, primates, pigs, ovines, goats, cervids, rodent and 
canids, with eggs that mature in soil. Eggs of Trichuris are characteristics in the shape of a barrel, with thick and smooth walls, and plugs at each pole. They hatch in the small intestine of the definitive hosts and the larvae migrate to the large intestine, where they penetrate the intestinal mucosa and develop through 4 molts before reaching the adult stage [25]. To date, a total of 24 species of Trichuris have been described from 10 families of American rodents [34]. Trichuris spp. in South American rodents from ancient material were reported $[10,12,35,36,37,38]$. Based on egg measurements, there were differences in the archaeofaunistic composition among the rodent middens, indicative of the existence of different Trichuris spp.

Rodents represent one of the most important sources of zoonoses for mammals and their increasing densities forced their dispersion to occur and brought them into closer contact with humans [39]. Species of Trichuris are included among the zoonotic geohelminths [40] since infection involves ingestion of contaminated soils. It seems probable that Trichuris spp., living in rodents from northwestern Patagonia, could be infectious for humans given that, during the Holocene, both humans and animals occupied caves and shelters.

A previous paleoparasitological study was done in $\mathrm{CH} 1$ [12], in this case coprolites were recolected from different levels of the cave, an archaeological site. In this case, micromammal coprolites were studied and were positive for Viscachataenia quadrata and Monoecocestus sp. (Cestoda: Anoplocephalidae) and for Heteroxynema (Cavioxyura) viscaciae (Nematoda: Oxyuridae). The coprolites examined were tentatively attributed to Lagidium viscacia. 
Midden fecal-pellet sizes and shapes are tools for distinguishing the midden-forming agents. In this study, based on the rodent species present in the study area [41], the aspect of fossil rodent middens and the coprolites examined, the eggs of the parasites found in this study, and the knowledge of the parasitic fauna of viscachas, the feces were attributed to Lagidium viscacia (Caviomorph: Chinchillidae) named "chinchillón or vizcacha serrana". This family comprises the genus Chinchilla (chinchillas), Lagidium (mountain viscachas), and Lagostomus (plains viscachas), mostly limited to the driest regions of western and southern South America, from the highlands of Ecuador through the Andes of Peru and Bolivia to the coastal mountains of Chile and Patagonian steppe of Argentina. Three species of Lagidium are recognized, one with an extensive distribution down the spine of the Andes, from southern Peru through Bolivia and northern Chile to central Argentina (L. viscacia,), a second from a small area in the mountains of west- central Argentina and adjacent to Chile (L. wolffsohni), and a third, recently described from southern Ecuador ( $L$. ahuacaense) [42].

Rodent middens in South America are discontinuous in nature but a fundamental multiproxy archive that provide the chance to peer in the past environmental and climatic dynamic of arid and semiarid areas [1,3]. From a paleoparasitological point of view, and based on the results of this paper, fossil rodent middens have proven to be an excellent source of parasites from the past. Thus, the good preservation of parasite remains in coprolites from fossil rodent middens provided an opportunity for paleoparasitological inferences. Fossil rodent middens offer an excellent opportunity for the recovery of parasite remains for future paleoparasitological studies in the southwest of South 
America. In order to improve the scale of the inferences, a larger number of middens will be needed to be robust regarding the parasite information. This paper, therefore, state the basis for future research employing rodent middens, an unexplored archive up to now for parasitological and paleoparasitological studies.

Acknowledgements: To Diego Verzi for his help with the identification of the rodents feces and to Jean-Pierre Hugot for his help with oxyurid parasites in caviomorphs. Project PICT 2014-0940 (Agencia Nacional de Promoción Científica y Tecnológica).

\section{BIBLIOGRAPHY}

[1] J.L. Betancourt, T.R. Van Devender, Martin,P.S. (Eds.), Packrat Middens: the last 40,000 years of biotic change, University of Arizona Press, Tucson, AZ, (1990), 467 pp.

[2] J.L. Betancourt, B. Saavedra, Paleomadrigueras de roedores, un nuevo método para el estudio del Cuaternario en zonas áridas de Sudamérica, Rev. Chil. Hist. Nat. 75 (2002) 527-572.

[3] J.L. Betancourt, C. Latorre, J.A. Rech, J. Quade, K.A. Rylander, A 22000 year record of monsoonal precipitation from northern Chile's Atacama Desert, Science 289 (2000) 1542-1546. 
[4] C. Latorre, J.L. Betancourt, K.A. Rylander, J. Quade, O. Matthei, A vegetation history from the arid prepuna of northern Chile $\left(22^{\circ}-23^{\circ} \mathrm{S}\right)$ over the last 13500 years, Palaeogeogr. Palaeoclimatol. Palaeoecol. 194 (2003) 223246.

[5] A.J. Maldonado, J.L. Betancourt, C. Latorre, C. Villagrán, Pollen analyses from a 50,000-yr rodent midden series in the southern Ataca Desert (25-30`S), J. Quaternary Sci. 20 (2005) 493-507.

[6] C.A. Holmgren, E. Rosello, C. Latorre, J.L. Betancourt, Late-Holocene fossil rodent middens from de Arica region of northernmost Chile, J. Arid. Environ. 72 (2008) 677-686.

[7] F.P. Díaz, C. Latorre, A. Maldonado, J. Quade, J.L. Betancourt, Rodent middens reveal episodic, long-distal plant colonization across the hyperarid Atacama desert over the last 34,000 years, J. Biogeography 39 (2012) 510-525.

[8] M.I. Mujica, C. Latorre, A. Maldonado, L. González-Silvestre, R. Pinto, R. de Pol-Holz, C.M. Santoro, Late Quaternary climate change, relict populations and present-day refugia in the northern Atacama Desert: a case study from Quebrada La Higuera (18 S), J. Biogeography 42 (2015) 76-88.

[9] F. Bouchet, N. Guidon, K. Dittmar, S. Harter, L.F. Ferreira, S.M. Chaves, K.J. Reinhard, A. Araujo, Parasite remains in archaeological sites, Mem. Inst. Oswaldo Cruz 98 (2003) 47-52.

[10] N.H. Sardella, M.H. Fugassa, Parasites in rodent coprolites from the historical archaeological site Alero Mazquiarán, Chubut Province, Argentina, Mem. Inst. Oswaldo Cruz 104 (2009a) 37-42. 
[11] N.H. Sardella, M.H. Fugassa, Paleoparasitological analysis of rodent coprolites in holocenic samples from Patagonia, Argentina, J. Parasitol. 95 (2009b) 646-651.

[12] N.H. Sardella, M.H. Fugassa, Paleoparasitological finding of eggs of nematodes in rodent coprolites dated at the Early Holocene from the archaeological site Cerro Casa de Piedra 7, Santa Cruz, Argentina, J. Parasitol. 97 (2011) 1184-1187.

[13] N.H. Sardella, M.H. Fugassa, D.D. Rindel, R.A. Goñi, Paleoparasitological results for rodent coprolites from Santa Cruz Province, Mem. Inst. Oswaldo Cruz 105 (2010) 33-40.

[14] M.O. Beltrame, N.H. Sardella, M.H., Fugassa, R. Barberena, Paleoparasitological analysis of rodent coprolites from the archaeological site Cueva Huenul 1, Patagonia (Argentina), Mem. Inst. Oswaldo Cruz 107 (2012) 604-608.

[15] M.O. Beltrame, M.H. Fugassa, R. Barberena, D.E. Udrizar Sauthier, N.H. Sardella, New record of anoplocephalid eggs (Cestoda: Anoplocephalidae), Parasitol. Internat. 62 (2013) 431-434.

[16] M.O. Beltrame, M.H. Fugassa, D.E. Udrizar Sauthier, N.H. Sardella, Paleoparasitological study of rodent coprolites from "Los Altares" paleontological site, Patagonia, Argentina, Quat. Internat. 352 (2014a) 59-63.

[17] M.O. Beltrame, M. Vieira de Souza, A. Araújo, N.H. Sardella, Review of the rodent paleoparasitological knowledge from South America, Quat. Internat. 352 (2014b) 68-74. 
[18] F.A. Roig, La vegetación de la Patagonia. Colección Científica INTA, Tomo VIII, vol. I. (1998).

[19] R.J.C. León, D. Bran, M. Collantes, J.M. Paruelo, A. Soriano, Grandes unidades de vegetación de la Patagonia extra andina, Ecol. Austral 8 (1998) 125-144.

[20] R. Barberena, Cueva Huenul 1 archaeological site, northwestern Patagonia, Argentina: initial colonization and mid-holocene demographic retraction, Lat. Amer. Antiq. 26 (2015) 304-318.

[21] R. Barberena, K. Borrazzo, A. Rughini, G. Romero, M.P. Pompei, C. Llano, M.E. De Porras, V. Durán, C.R. Sterno, A. Re, D. Estrella, A. Forasiepi, F.J. Fernández, M. Chidiak, L. Acuña, A. Gasco, M.N. Quiroga, Perspectivas arqueológicas para Patagonia Septentrional: Sitio Cueva Huenul 1 (Provincia del Neuquén, Argentina), Magallania 43 (2015) 1-27.

[22] M. Chame, Terrestrial mammal feces: a morphometric summary and description, Mem. Instit. Oswaldo Cruz 98 (2003) 71-94.

[23] F. Jouy-Avantin, A standarized method for the description and study of coprolites, J. Archaeol. Sci. 30 (2003) 367-372.

[24] A. Lutz, Schistosoma mansoni e a schistosomatose segundo observaçoes feitas no Brasil, Mem. Inst. Oswaldo Cruz 1 (1919) 121-155.

[25] R.C. Anderson, Nematode parasites of vertebrates: Their development and transmission. CAB International, Wallingford, UK (2000) 650 pp. 
[26] A.J. Petter, J-C. Quentin, Oxyurida. In: R.C. Anderson, A.G. Chabaud, S. Willmott (Eds.). Keys to the nematode parasites of vertebrates, Archival Volume, CAB International, Wallingford, UK (2009) pp. 218-247.

[27[ J.P. Hugot, C.A. Sutton, Contribution à la connaissance de la faune parasitaire d' Argentine, XV. Etude morphologique de Heteroxynema (Cavioxyura) viscaciae n. sp. (Nematoda, Heteroxynematidae) parasite de Lagidium viscacia boxi (Mammalia, Rodentia), Sys. Parasitol. 13 (1989a) 111120.

[28] G.W. Foster, L.C. Branch, M. Marchiote, J.M. Kinsella, D. Villarreal, D.J. Forrester, Gastrointestinal helminths of the plains vizcacha (Lagostomus maximus) from Argentina, with observations on interspecific interactions between nematodes and cestodes, Comp. Parasitol. 69 (2002) 26-32.

[29] H. Ferreira, M.M. Uhart, M.C. Romano, P.M. Beldoménico, L. Samartino, F. Paolicchi, M. Lauricella, M.C. Jorge, A. Schettino, N. Guida, A.M. Martín, A.M., Inmovilización química y evaluación de salud de vizcachas salvajes (Lagostomus maximus) en el Chaco árido argentino, Arq. Ciênc. Vet. Zool. Unipar 10 (2007) 91-99.

[30] H. Hasegawa, K. Matsuo, M. Onuma, Enterobius (Colobenterobius) serratus sp. nov. (Nematoda: Oxyuridae) from the proboscis monkey, Nasalis larvatus (Wurmb 1787) Primates: Cercopithecidae: Colobinae, in Sarawak, Borneo, Malaysia, Comp. Parasitol. 70 (2003) 128-131.

[31] J.P. Hugot, C. Feliu, B. Douangboupha, A. Ribas, Laoxyuris laonastin. gen., n. sp. (Nematoda: Syphaciinae) parasite of Laonastes aenigmamus 
(Rodentia: Diatomyidae): Morphology, biology, taxonomy, phylogeny, Infect. Genet. Evol. 16 (2013) 113-121.

[32] J.P. Hugot, S.L. Gardner, Helminthoxys abrocomae n. sp. (Nematoda:

Oxyurida) from Abrocoma cinerea in Bolivia, Syst. Parasitol. 47 (2000), 223230.

[33] J.P. Hugot, C.A. Sutton, Étude morphologique de deux oxyures appartenant au genre Helminthoxys, Bull. Mus. Natl. Hist. Nat. 4,11 (A) $n^{\circ} 2$ (1989b) 387-395.

[34] M.R. Robles, G.T. Navone, New host records and geographic distribution of species of Trichuris (Nematoda: Trichuridae) in rodents from Argentina with an updated summary of records from America, Mastozool. Neotrop. 21 (2014) 67-78. [35] L.F. Ferreira, A. Araújo, U. Confalonieri, M. Chame, D.C. Gomes, Trichuris eggs in animal coprolites dated from 30,000 years ago, J. Parasitol. 77 (1991) 491-493.

[36] A. Araújo, A. Rangel, L.F. Ferreira, Climatic change in Northern Brazil Paleoparasitological data, Mem. Inst. Oswaldo Cruz 88 (1993) 577-579.

[37] M.H. Fugassa, Enteroparasitosis en poblaciones Cazadoras-Recolectoras de Patagonia Austral. PhD Thesis, Universidad Nacional de Mar del Plata, Mar del Plata, Argentina (2006) 276 pp.

[38] M.O. Beltrame, M.H. Fugassa, N.H. Sardella, M.T. Civalero, C. Aschero, Raptor pellets as zooarchaeological material for paleoparasitological studies in Patagonia, J. Archaeol. Sci. 38 (2011) 1511-1515. 
[39] S.E. Perkins, I. Cattadori, P.J. Hudson, The role of mammals in emerging zoonoses, Mammal Study 30 (2005) 67-71.

[40] M.S. Wong, D.A.P. Bundy, Quantitative assessment of contamination of soil by the eggs of Ascaris lumbricoides and Trichuris trichiura, Trans. R. Soc. Trop. Med. Hyg. 84 (1990) 567-570.

[41] J.L. Patton, U.F.J. Pardiñas, G. D' Elía, Mammals of South America, Vol 2. Rodents. The University of Chicago Press. ISBN-13: 978- 0- 226-16960-6 (2015) $1334 \mathrm{pp}$.

[42] A.G. Hogg, Q. Hua, P.G. Blackwell, M. Niu, C.E. Buck, T.P. Guilderson, T.J. Heaton, J.G. Palmer, P.J. Reimer, R.W. Reimer, C.S.M. Turney, S.R.H. Zimmerman, SHCal13 Southern hemisphere calibration, 0-50,000 years cal BP, Radiocarbon 55 (2013) 1889-1903.

\section{Figure captions:}

Figure 1: Photographs showing a. Cueva Huenul $1(\mathrm{CH} 1)$; b. gorge close to $\mathrm{CH} 1$; c. and d. rodent middens collected at Huenul site.

Figure 2: Macroscopic aspect of the examined coprolites.

Figure 3: Egg of Heteroxynema viscaciae (Nematoda: Oxyuridae) observed from fossil rodent middens. Bar $=20 \mu \mathrm{m}$.

Figure 4: Egg of Helminthoxys sp. (Nematoda: Oxyuridae) observed from fossil rodent middens. Bar $=20 \mu \mathrm{m}$. 
Figure 5: Eggs of Trichuris sp. (Nematoda: Trichuridae) observed from fossil rodent middens. Bar $=20 \mu \mathrm{m}$.

Figure 6: Egg of unidentified nematode observed from fossil rodent middens. $B a r=20 \mu \mathrm{m}$. 


\section{ACCEPTED MANUSCRIPT}
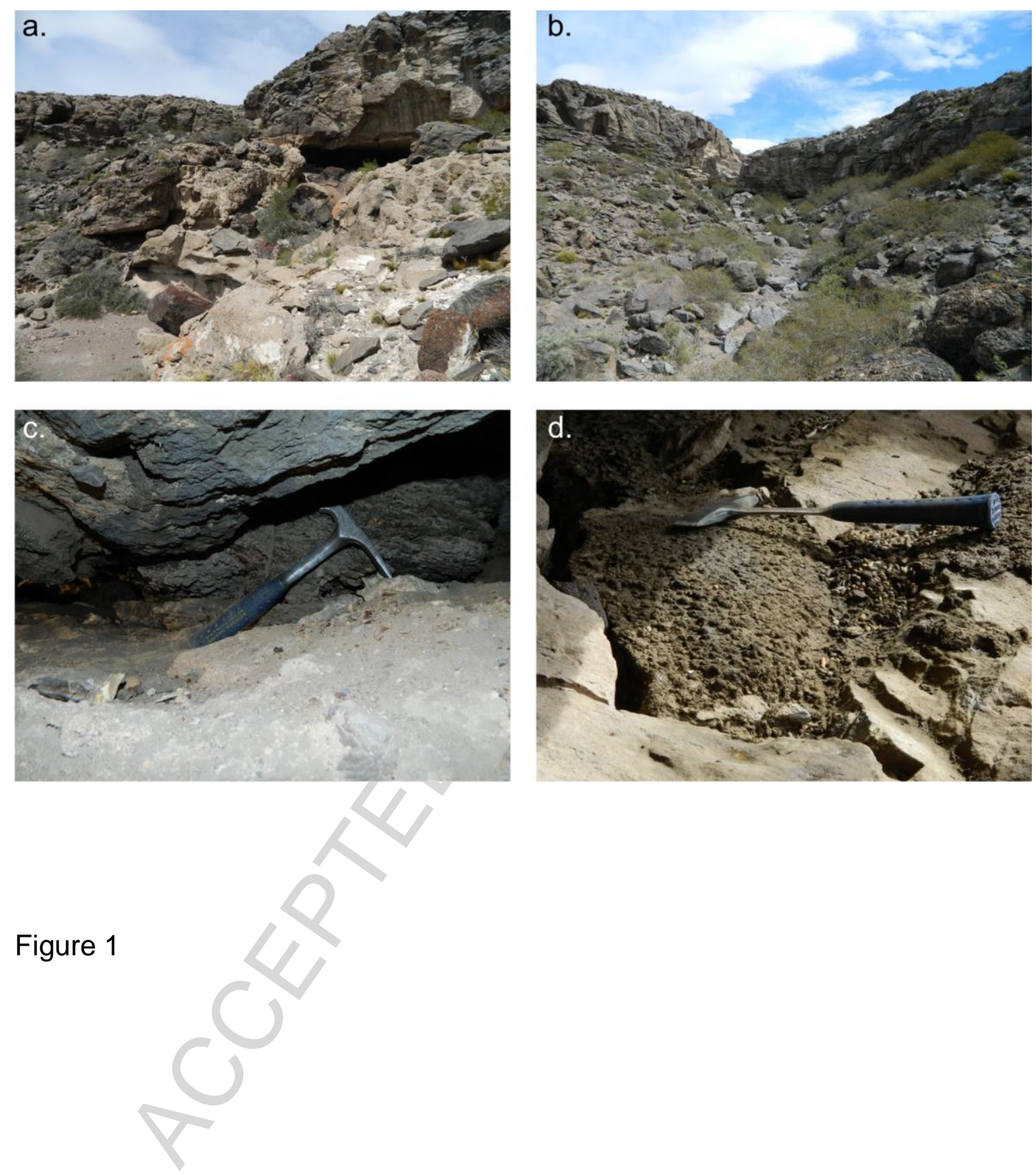


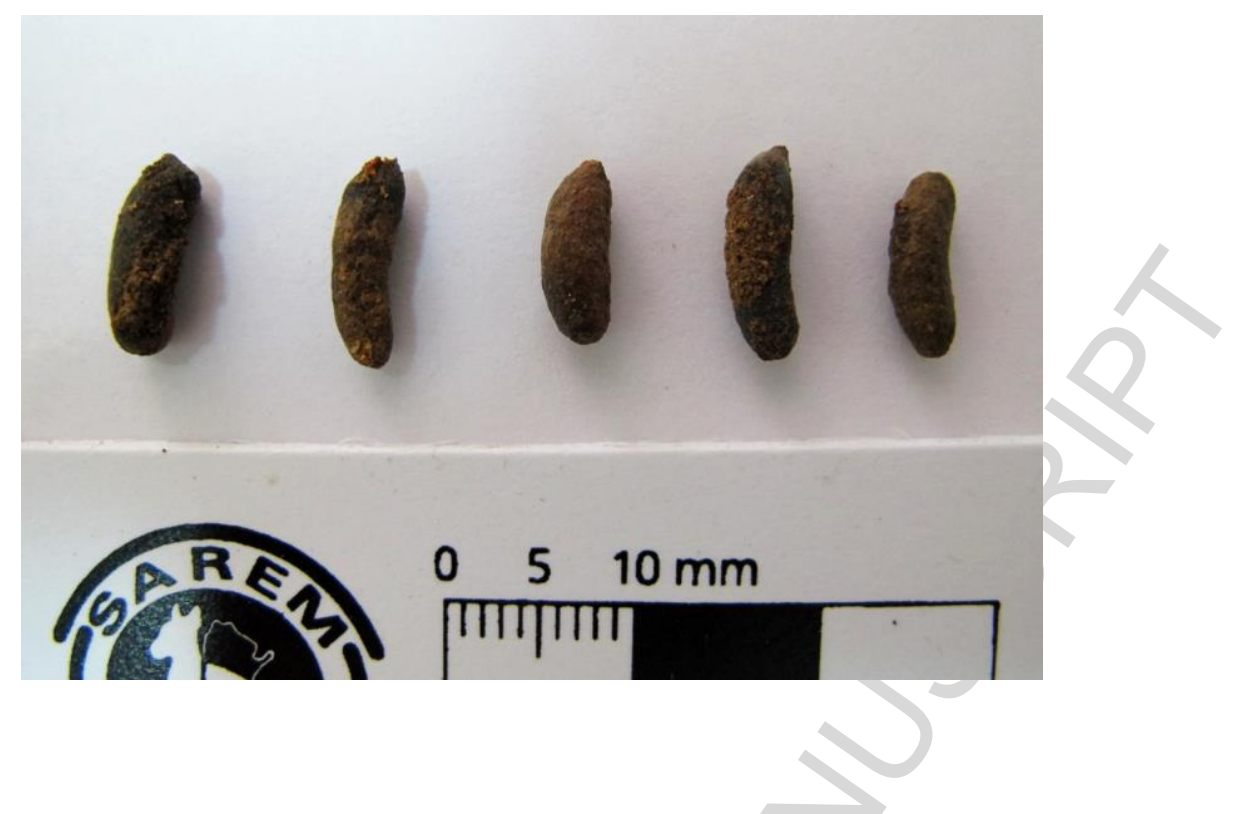

Figure 2 


\section{ACCEPTED MANUSCRIPT}

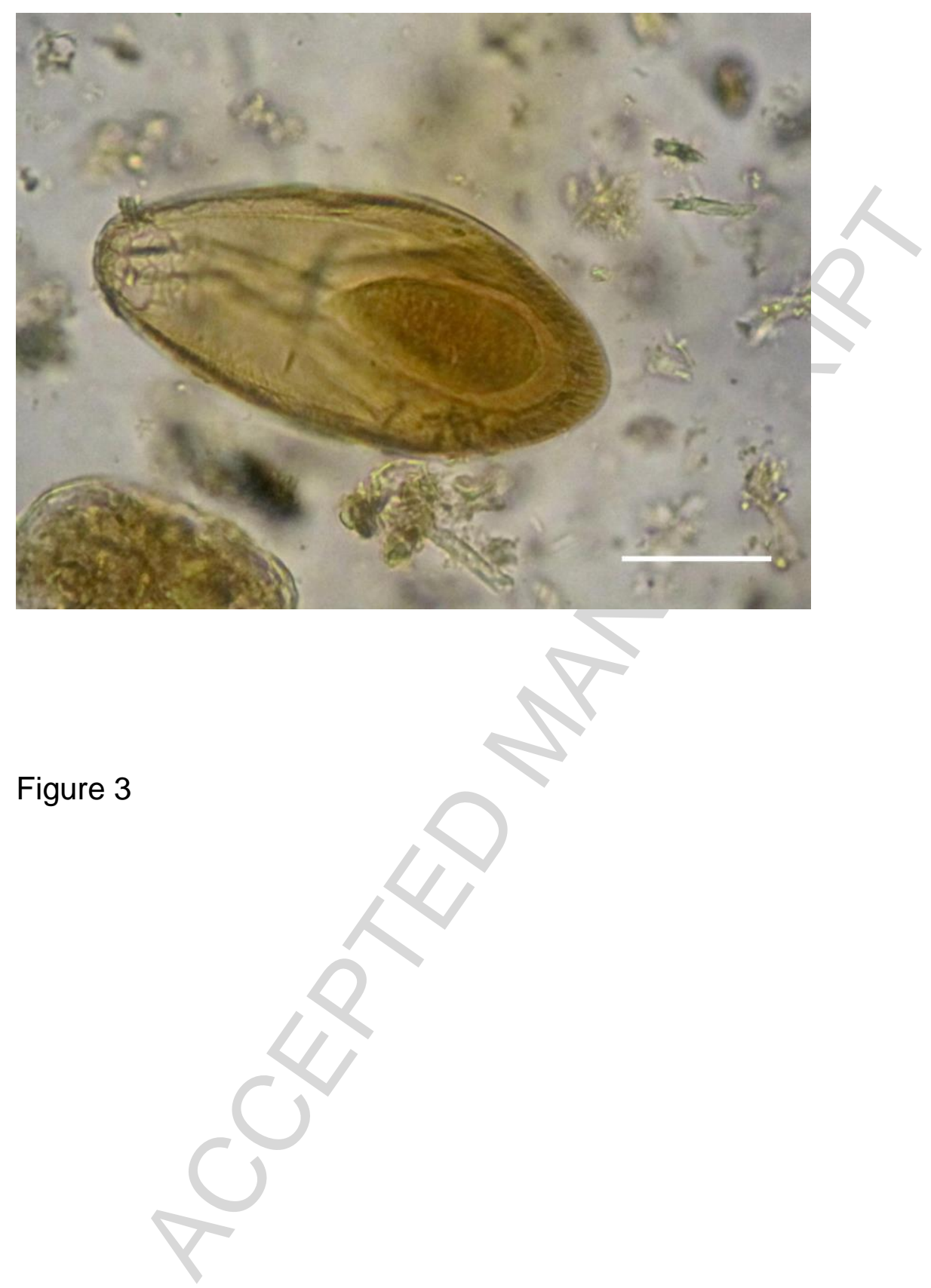




\section{ACCEPTED MANUSCRIPT}

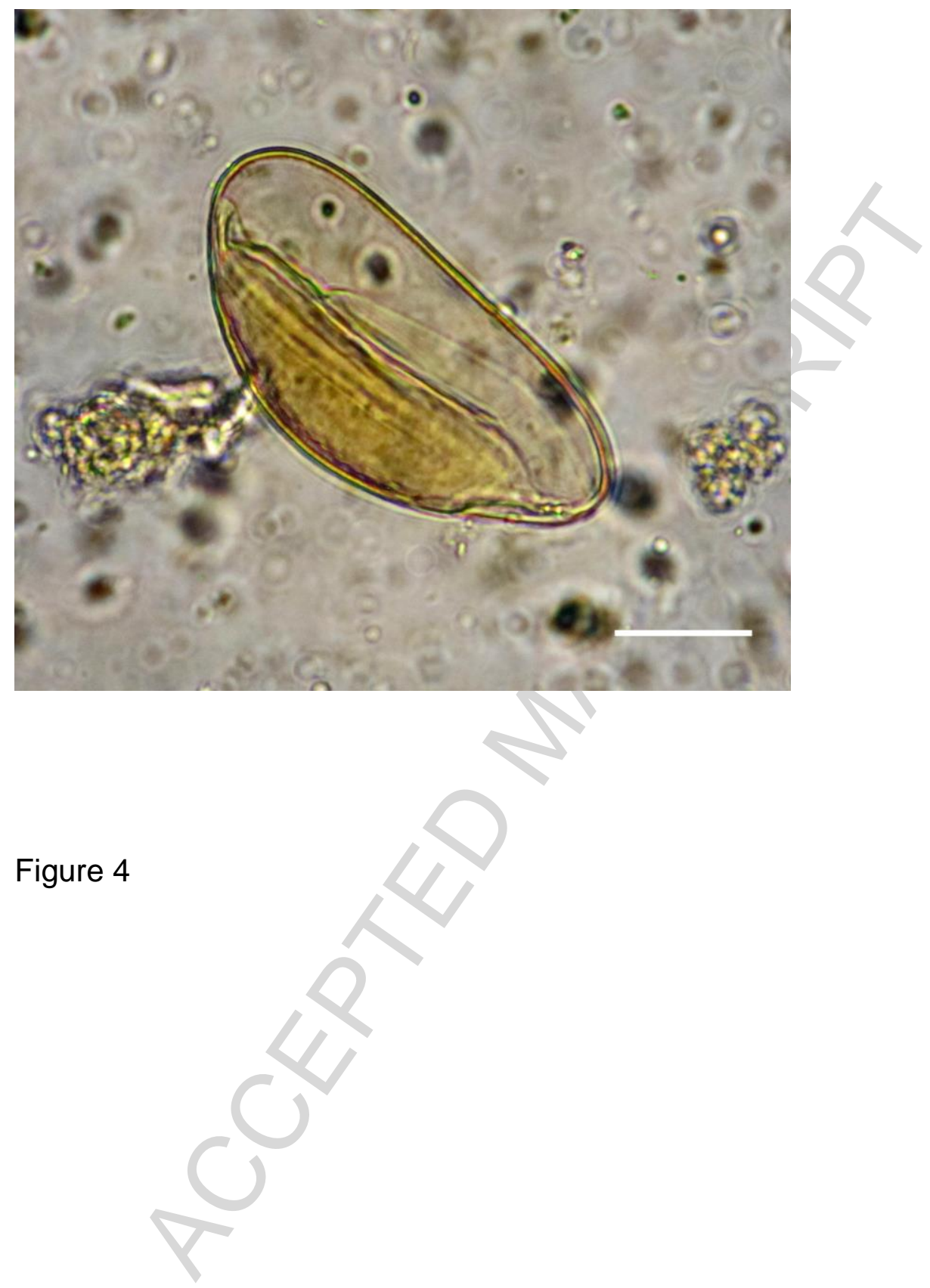




\section{ACCEPTED MANUSCRIPT}

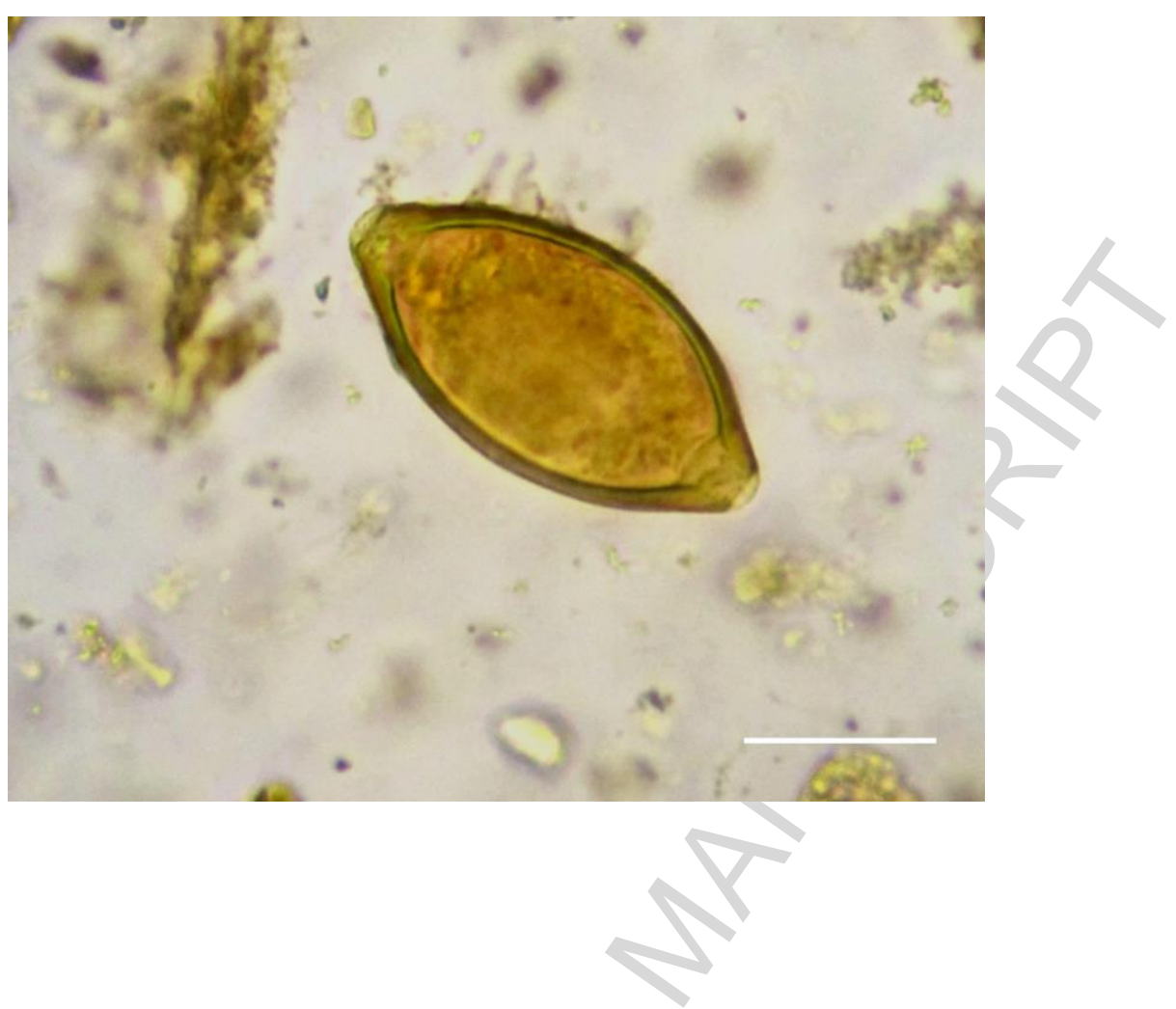

Figure 5

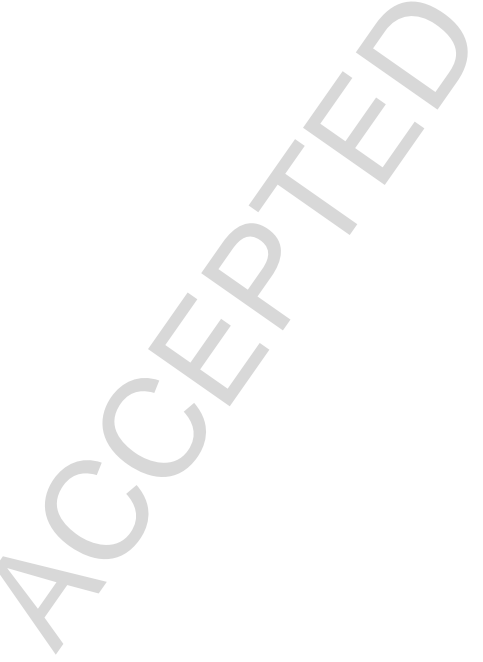


ACCEPTED MANUSCRIPT

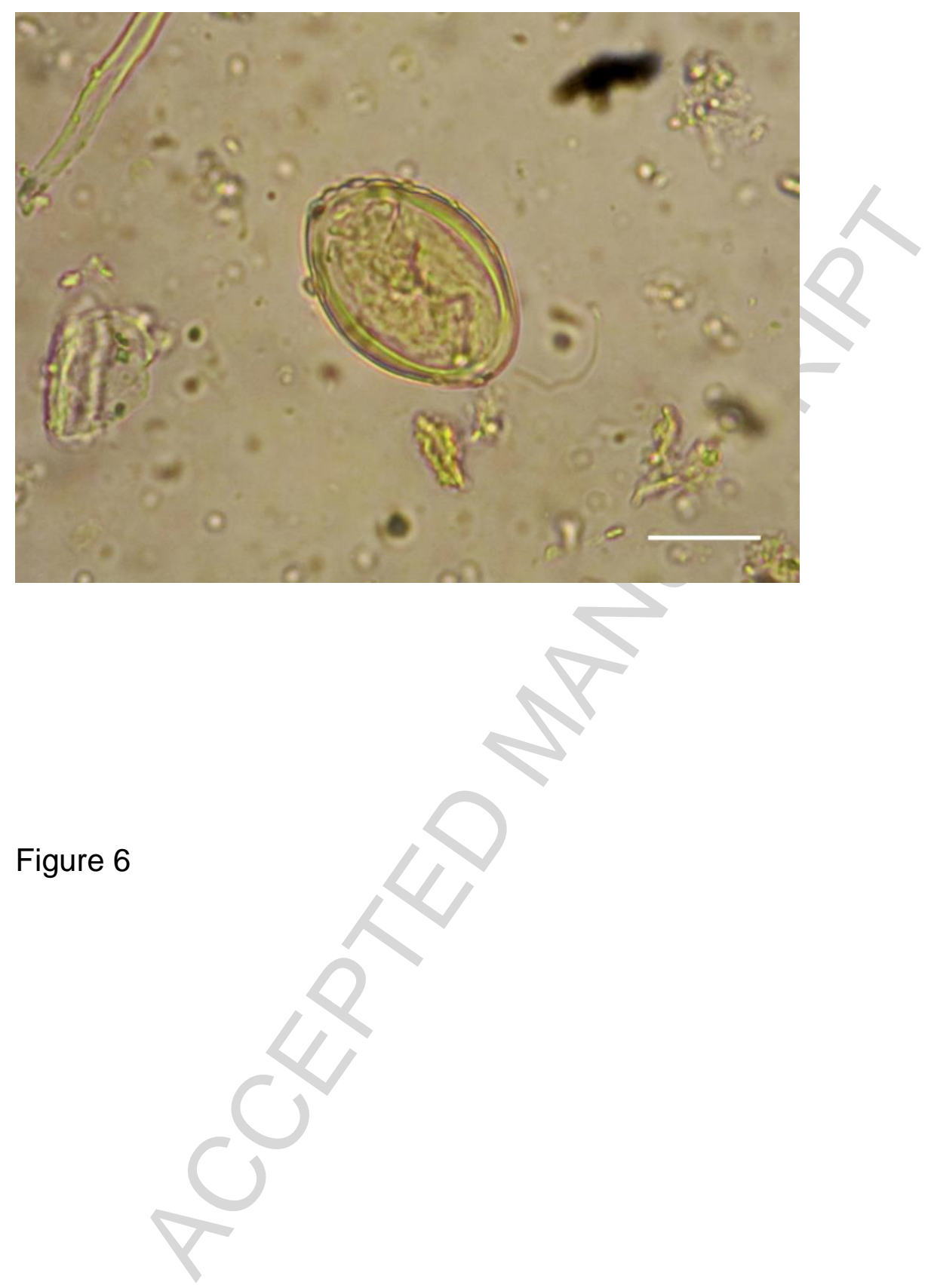


Table 1: Locality, height, age and parasites found from all fossil rodent middens studied from Huenul site, northwestern Patagonia, Argentina.

\begin{tabular}{|c|c|c|c|c|c|}
\hline Midden & locality & $\begin{array}{l}\text { Height } \\
\text { (m) }\end{array}$ & $\begin{array}{l}\text { Age (yrs } \\
\text { BP) }\end{array}$ & $\begin{array}{l}\text { Age (cal } \\
\text { yrs BP) }\end{array}$ & Parasites found \\
\hline HU584B & $\begin{array}{l}36^{\circ} 57^{\prime} 34.7^{\prime \prime} \mathrm{S} \\
69^{\circ} 49^{\prime} 40.3{ }^{\prime} \mathrm{W}\end{array}$ & 1,167 & & & negative \\
\hline HU558D & $\begin{array}{l}36^{\circ} 57^{\prime} 32.9^{\prime \prime} \mathrm{S} \\
69^{\circ} 49^{\prime} 21.7^{\prime \prime} \mathrm{W}\end{array}$ & 1,145 & $\begin{array}{c}5,730 \pm \\
70\end{array}$ & 6,480 & Trichuris sp. \\
\hline HU558E1 & $\begin{array}{l}36^{\circ} 57^{\prime} 32.9^{\prime \prime} \mathrm{S} \\
69^{\circ} 49^{\prime} 21.7^{\prime \prime} \mathrm{W}\end{array}$ & 1,145 & & & $\begin{array}{l}\text { Heteroxynema viscaciae, } \\
\text { Trichuris sp. }\end{array}$ \\
\hline HU582-1 & $\begin{array}{l}36^{\circ} 57^{\prime} 31.0^{\prime} \mathrm{S} \\
69^{\circ} 49^{\prime} 34.0^{\prime \prime} \mathrm{W}\end{array}$ & & $\begin{array}{c}8,280 \pm \\
120\end{array}$ & 9,213 & Helminthoxys sp. \\
\hline HU559A & $\begin{array}{l}36^{\circ} 57^{\prime} 31.0^{\prime \prime} \mathrm{S} \\
69^{\circ} 49^{\prime} 34.0^{\prime \prime} \mathrm{W}\end{array}$ & 1,171 & $\begin{array}{c}2,540 \pm \\
80\end{array}$ & 2,569 & H. viscaciae, Trichuris sp. \\
\hline HU584A & $\begin{array}{l}36^{\circ} 57^{\prime} 34.7^{\prime \prime} \mathrm{S} \\
69^{\circ} 49^{\prime} 40.3^{\prime \prime} \mathrm{W}\end{array}$ & 1,167 & $\begin{array}{c}3,320 \pm \\
90\end{array}$ & 3,512 & H. viscaciae, Helminthoxys sp. \\
\hline HU558A2 & $\begin{array}{l}36^{\circ} 57^{\prime} 32.9{ }^{\prime \prime} \mathrm{S} \\
69^{\circ} 49^{\prime} 21.7^{\prime \prime} \mathrm{W}\end{array}$ & 1,145 & $\begin{array}{c}8,920 \pm \\
180\end{array}$ & 9,947 & negative \\
\hline HU558A1 & $\begin{array}{l}36^{\circ} 57^{\prime} 32.9^{\prime} \mathrm{S} \\
69^{\circ} 49^{\prime} 21.7^{\prime} \mathrm{W}\end{array}$ & 1,145 & $\begin{array}{c}9,240 \pm \\
130\end{array}$ & 10,389 & H. viscaciae, Helminthoxys sp. \\
\hline HU558C & $\begin{array}{l}36^{\circ} 57^{\prime} 32.9^{\prime \prime} \mathrm{S} \\
69^{\circ} 49^{\prime} 21.7^{\prime \prime} \mathrm{W}\end{array}$ & 1,145 & $\begin{array}{c}8,680 \pm \\
120\end{array}$ & 9,963 & $\begin{array}{l}\text { Helminthoxys sp., unidentified } \\
\text { nematode }\end{array}$ \\
\hline HU558E2 & $36^{\circ} 57^{\prime} 32.9$ '’ $\mathrm{S}$ & 1,145 & $8,830 \pm$ & 9,834 & Trichuris sp., Helminthoxys sp. \\
\hline
\end{tabular}




\section{ACCEPTED MANUSCRIPT}

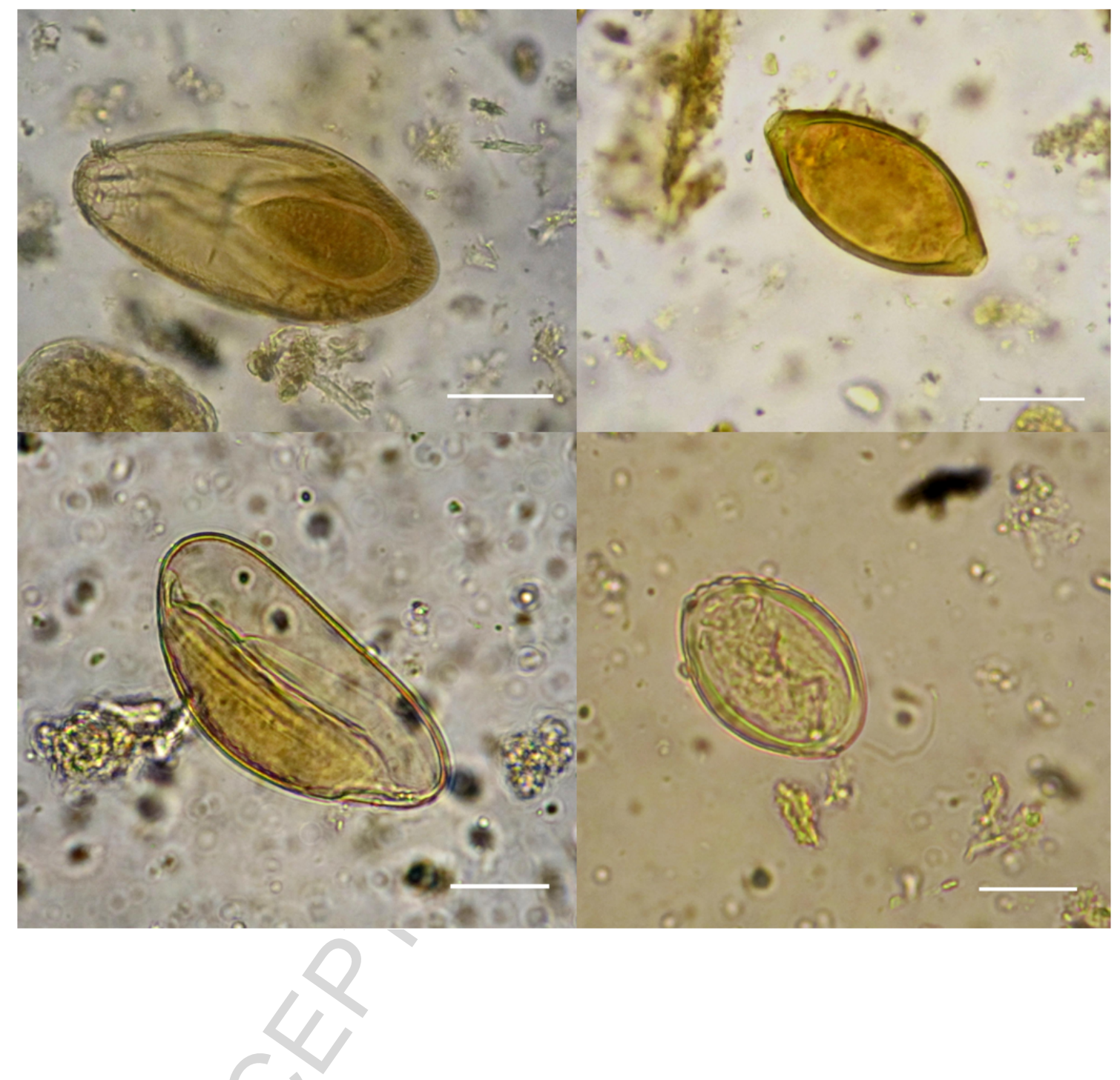

Graphical abstract 
Highlights

- Fist paleoparasitological results from coprolites of fossil rodent middens

- Coprolites from 10 fossil middens (northwestern Patagonia, Argentina) were studied

- Parasite remains in excellent preservation were found in coprolites

- Fossil rodent middens were assigned to Lagidium viscacia (Caviomorph)

- Middens offer an excellent opportunity for the recovery of ancient parasite remains 